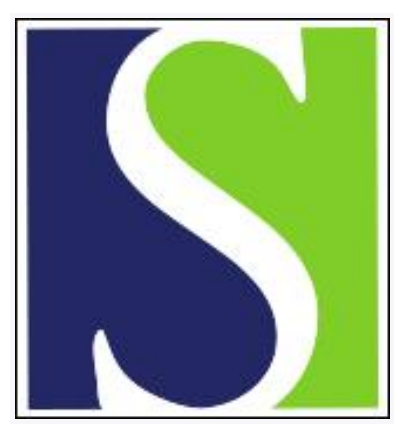

Scand J Work Environ Health 1992;18(2):120-123

https://doi.org/10.5271/sjweh.1602

Issue date: 01 Apr 1992

Carcinogens in rubber production in the Soviet Union.

by Solionova LG, Smulevich VB, Turbin EV, Krivosheyeva LV, Plotnikov JV

Affiliation: All-Union Cancer Research Center AMS USSR, Laboratory of Occupational Cancer, Moscow, Commonwealth of Independent States.

This article in PubMed: www.ncbi.nlm.nih.gov/pubmed/1604272

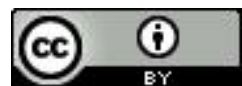




\title{
Carcinogens in rubber production in the Soviet Union
}

\author{
by Liya G Solionova, PhD, ${ }^{1}$ Vladimir B Smulevich, MD, ${ }^{1}$ Evgeni V Turbin, MD, ${ }^{2}$ \\ Leyla V Krivosheyeva, PhD, ${ }^{1}$ Juri V Plotnikov ${ }^{1}$
}

\begin{abstract}
SOLIONOVA LG, SMULEVICH VB, TURBIN EV, KRIVOSHEYEVA LV, PLOTNIKOV JV. Carcinogens in rubber production in the Soviet Union. Scand $J$ Work Environ Health 1992;18:120-3. In a preliminary phase of a broad research project on cancer among workers in a rubber footwear plant in Moscow, exposure to several known or potential carcinogens was assessed. There were high dust contents bearing both toxic substances and carcinogens. The highest concentrations of benzo[a]pyrene $(500-14400 \mu \mathrm{g})$ were found on the soot used as a filler, and the maximum $\mathrm{N}$-dimethylnitrosamine (DMNA) level was measured in thiram $\left(150-23868 \mu \mathrm{g} \cdot \mathrm{kg}^{-1}\right)$. Air samples from the vulcanization process and the pressing of rubber goods showed BaP levels of up to $1.43 \mu \mathrm{g} \cdot \mathrm{m}^{-3}$. In the work area where polyvinyl chloride was used, the mean vinyl chloride concentration was 0.21 (SE 0.06$) \mathrm{mg}^{\cdot} \mathrm{m}^{-3}$. The mean value of the acrylonitrile concentrations in the workroom area was $0.19(\mathrm{SE} 0.07) \mathrm{mg}^{\prime} \cdot \mathrm{m}^{-3}$. Very high levels of DMNA and N-diethylnitrosamine were measured in the preparatory shop in the winter.
\end{abstract}

Key terms: benzo[a]pyrene, N-nitrosamines, rubber chemicals, workplace exposure.

As assessed from epidemiologic evidence obtained in Great Britain $(1,2)$, the United States (3-6), the Nordic countries, and elsewhere $(7,8)$ by experts of the International Agency for Research on Cancer (IARC), the production of rubber involves a high carcinogenic risk for humans (8). For rubber workers, causal relationships have been identified between exposure to aromatic amines and bladder cancer and between exposure to solvents and leukemia. Increased risks have also been shown for, for example, gastrointestinal tumors and lung and skin cancers, but the causes are not yet known.

In rubber production the epidemiologist has to deal with complex exposures because a whole spectrum of chemicals, including rubber mixture ingredients, their pollutants and derivates, and newly synthesized chemicals, is involved throughout the entire process. These airborne pollutants can attain the form of aerosols and gases. Since it is almost impossible to separate the health effects of concurrent exposure to the various agents, the occupational risks are often defined in terms of particular jobs and workplaces sharing common physical or chemical exposure (dust, vulcanization gases, solvents, etc). In addition, contradicting results of some epidemiologic studies indicate the important role of local conditions pertinent to, for example, a particular technology, specific ingredients, and type of equipment. Therefore hygienic characteris-

1 All-Union Cancer Research Center AMS USSR, Laboratory of Occupational Cancer, Moscow, Commonwealth of Independent States.

2 The Institute of Industrial Hygiene and Occupational Diseases AMS USSR, Moscow, Commonwealth of Independent States.

Reprint requests to: Dr LG Solionova, All-Union Cancer Research Center, Laboratory of Occupational Cancer, Kashirscoye shosse 24, Moscow 115478, CIS. tics often provide clues for the estimation of particular occupational carcinogens.

The rubber industry heads the list of branches in which employees are substantially exposed to N-nitrosamines (N-NA) $(9,10)$. This exposure may explain the employees' increased risk of brain cancer $(11,12)$. Nevertheless an overall estimation of the carcinogenic action of N-NA in an industrial setting is still lacking.

As a part of a broad research project on cancer among rubber workers employed at one of the oldest rubber footwear plants in the Soviet Union, a complex assessment of work conditions and exposure to such known or potential carcinogens as benzo[a]pyrene $(\mathrm{BaP}), \mathrm{N}-\mathrm{NA}$, vinyl chloride, and acrylonitrile was undertaken. Its principal results are reported in this communication.

\section{Materials and methods}

Samples of the raw rubber mixture were taken in the preparatory shop to be analyzed for BaP and N-NA as potential sources of leakage into the workplace air.

Ambient air samples were also taken from various worksites (both permanent and temporary) at different stages of rubber production and were analyzed for their dust and chemical contents. Breathing-zone samples were collected during the workday between 0900 and 1500 (the morning shift). The air was sampled at a flow rate of $10 \mathrm{l} \cdot \mathrm{min}^{-1}$ for $10 \mathrm{~min}$ through paper filters. The dust content $\left(\mathrm{mg} \cdot \mathrm{m}^{-3}\right)$ was determined from the weight of the filter and the volume of the aspirated air. Afterwards, a spectrophotometric method was used to determine the levels of soot, diaphene, thiram, talc, and sulfur. For production operations in which only talc or sulfur were used, the contents of these substances were determined from the change in the weight 
of the filter. These methods had a detection limit of $<0.5$ of the occupational exposure limit. The precision of the measurements was no greater than $25 \%$, which corresponds to State All-Union Standard No 121.016.79. of the System of Job Safety Standards.

Gas-liquid chromatography with a flame-ionization detector was used to determine the vinyl chloride and acrylonitrile contents. The air for the vinyl chloride identification was sampled at a flow rate $0.21 \cdot \mathrm{min}^{-1}$ for $5 \mathrm{~min}$ through an activated charcoal sampling tube, which was then submitted to thermodesorption. The samples for acrylonitrile were collected into glass syringes without concentration. The detection limit of the methods was $0.005 \mu \mathrm{g}$.

For the $\mathrm{BaP}$ analysis of the soot and paper filters a routine method was used, including sample extraction with benzene in an ultrasonic bath, thin-layer chromatography of the extracts on aluminum oxide, and quantitative analysis of quasilinear luminescent spectra at low temperatures $\left(+77^{\circ} \mathrm{K}\right)$, the analysis being based on Shpolsky's effect as modified by Khesina (13). The method has a detection limit of $0.0001 \mu \mathrm{g} \cdot \mathrm{ml}^{-1}$. The precision of the measurements was $\pm 10 \%$.

For the N-NA analysis, the air samples were aspirated through three consecutively connected traps filled with a $1 \mathrm{~N}$ solution of potassium hydroxide. An aqueous solution of $\mathrm{N}$-nitrosodipropylamine was used as an internal standard. The combined sample was subjected three times to extraction with dichloromethane $\left(\mathrm{CH}_{2} \mathrm{Cl}_{2}\right)$. The extract was dried with anhydrous sodium sulfate $\left(\mathrm{Na}_{2} \mathrm{SO}_{4}\right)$, concentrated to $5 \mathrm{ml}$ with a gentle stream of nitrogen at a temperature of $40^{\circ} \mathrm{C}$, and then concentrated to $1 \mathrm{ml}$ at a temperature of $22^{\circ} \mathrm{C}$. Volatile N-NA was extracted from the compounds of the raw rubber mixture with $\mathrm{CH}_{2} \mathrm{Cl}_{2}$ (double extraction in an ultrasonic bath) with subsequent distillation with water vapor. The $\mathrm{CH}_{2} \mathrm{Cl}_{2}$ extract (dried with anhydrous $\mathrm{Na}_{2} \mathrm{SO}_{4}$ ) was concentrated as has already been described. Further analysis was conducted with gas chromatography ("Tzvet," CIS), a thermal energy analyzer (TEA-502A, USA) being used as the detector. The method has a limit of detection of $0.05 \mu \mathrm{g}$. The precision of the recovery measurements was $\pm 10 \%$. To ensure the absence of traces of N-NA or interfering material, a test was performed using the same procedure, but omitting the sample.

\section{Results}

Soot is a necessary compound of rubber mixtures. However, it adsorbs significant amounts of carcinogenic polycyclic aromatic hydrocarbons (PAH). Four brands of industrial soot were tested, and the variation in the $\mathrm{BaP}$ levels ranged from 500 to 14400 $\mu \mathrm{g} \cdot \mathrm{kg}^{-1}$. The preparatory shop was characterized by very unfavorable work conditions. There were high levels of diaphene (2-7 times the occupational exposure limit), soot ( 5 times the occupational exposure limit), and thiram and talc (10-20 times the occupational exposure limit) - see table 1. At subsequent stages of the rubber production (calendering, cutting, production, and vulcanization) the average concentrations of dust and soot were 1.3 (SE 0.14) and 0.015(SE $0.002) \mathrm{mg} \cdot \mathrm{m}^{-3}$, respectively.

The analysis of the BaP content at the various technological stages showed that, contrary to expectations, the maximum levels did not occur in the preparatory shop (where it is adsorbed on airborne dust and soot), but rather in the vulcanization shop. Presumably due to the high temperatures $\left(170-180^{\circ} \mathrm{C}\right)$, partial rubber pyrolysis takes place during the vulcanization process and results in the production of $\mathrm{BaP}$ and other PAH. In this shop the mean BaP level exceeded the occupational exposure limit, which was $0.15 \mu \mathrm{g}$. $\mathrm{m}^{-3}$, and in some air samples the excess was 5- to 10-fold the occupational exposure limit (table 2). A comparison of the BaP contents in the air of the vulcanization shop with the press closed $\left(0.043 \mu \mathrm{g} \cdot \mathrm{m}^{-3}\right)$ and at the instant of its opening (in the stream of emission $0.16 \mu \mathrm{g} \cdot \mathrm{m}^{-3}$ ) indicated that, during vulcanization, active $\mathrm{BaP}$ emission occurs, and after the opening of the press BaP disseminates around the shop.

At the studied plant, polyvinyl chloride (PVC) goods are produced along with traditional rubber products. Thirty-two air samples from the section casting PVC goods were analyzed for vinyl chloride. In the samples $(\mathrm{N}=24)$ taken at the worksite of the operator of the casting conveyer and near the press, the vinyl chlo-

Table 1. Time-weighted average concentrations of airborne contaminents in the breathing zone of workers in the preparatory shop (SE = standard error)

\begin{tabular}{|c|c|c|c|c|c|}
\hline \multirow[b]{2}{*}{ Material } & \multirow{2}{*}{$\underset{(N)}{\text { Samples }}$} & \multicolumn{3}{|c|}{ Concentration $\left(\mathrm{mg} \cdot \mathrm{m}^{-3}\right)$} & \multirow{2}{*}{$\begin{array}{l}\text { Occupational exposure } \\
\text { limit in the Soviet } \\
\text { Union } \\
\left(\mathrm{mg} \cdot \mathrm{m}^{-3}\right)\end{array}$} \\
\hline & & Mean & SE & Range & \\
\hline $\begin{array}{l}\text { Soot } \\
\text { Diaphene } \\
\text { Thiramb }^{b} \\
\text { Talc } \\
\text { Sulfur }\end{array}$ & $\begin{array}{l}48 \\
48 \\
48 \\
48 \\
32\end{array}$ & $\begin{array}{r}11.2 \\
8.3 \\
5.9 \\
86.1 \\
3.9\end{array}$ & $\begin{array}{l}1.4 \\
1.6 \\
0.3 \\
7.6 \\
0.9\end{array}$ & $\begin{array}{c}4.2-24.2 \\
4.4-15.0 \\
2.4-10.0 \\
57.7-121.1 \\
2.2-6.6\end{array}$ & $\begin{array}{l}4.0 \\
2.0 \\
0.5 \\
4.0 \\
6.0\end{array}$ \\
\hline
\end{tabular}

a $\mathrm{N}$-phenyl-N'-isopropyl-p-phenylenediamine.

b Tetramethylthiram disulfide. 
Table 2. Time-weighted average concentrations of benzo(a)pyrene in the breathing zone of workers during footwear production. ( $\mathrm{SE}=$ standard error)

\begin{tabular}{lcccc}
\hline \multirow{2}{*}{ Type of process } & \multirow{2}{*}{$\begin{array}{c}\text { Samples } \\
(\mathrm{N})\end{array}$} & \multicolumn{3}{c}{ Concentration $\left(\mu \mathrm{g} \cdot \mathrm{m}^{-3}\right)$} \\
\cline { 3 - 5 } & & Mean & SE & Range \\
\hline Raw material handling, weighing, mixing & 48 & 0.022 & 0.003 & $0.015-0.13$ \\
Milling, extruding & 3 & 0.026 & 0.01 & $0.005-0.076$ \\
Assembly and building & 25 & 0.04 & 0.03 & $0.001-0.243$ \\
Curing or vulcanizing & 5 & 0.26 & 0.07 & $0.01-1.43$ \\
Inspection and finishing & 12 & 0.14 & 0.002 & $0.005-0.21$ \\
Footwear casting & & 0.020 & 0.005 & $0.001-0.055$ \\
\hline
\end{tabular}

Table 3. N-nitrosamine concentrations in rubber chemicals. ( $\mathrm{N}$-DMNA = dimethylnitrosamine, N-DENA = diethylnitrosamine)

\begin{tabular}{lccc}
\hline & \multirow{2}{*}{$\begin{array}{c}\text { Samples } \\
\text { Chemicals }\end{array}$} & \multicolumn{2}{c}{ Concentration $\left(\mu \mathrm{g} \cdot \mathrm{kg}^{-1}\right)$} \\
\cline { 3 - 4 } & 1 & 1.1 & Trace $^{\mathrm{a}}$ \\
\hline Diaphene & 1 & 1.9 & Trace $^{\mathrm{a}}$ \\
Carbamate & 1 & 4.4 & Trace $^{\mathrm{a}}$ \\
Sulfenamide & & & \\
Altaks (2,2-dibenz- & 1 & 6.1 & 4.5 \\
thiazol disulfide) & 1 & 11.2 & 42.4 \\
Azodicarbonamide & 2 & $1.4 ; 150.0$ & $1.9 ; 26.6$ \\
Diphenylguanidine & 2 & 2300.0 & 690.0 \\
Diphenylnitrosamine & 1 & &
\end{tabular}

\begin{tabular}{llll}
$\begin{array}{l}\text { Thiram (tetramethyl- } \\
\text { thiuram disulfide) }\end{array}$ & 2 & $150.0 ; 22868.0$ & Trace $^{a}$ \\
\hline
\end{tabular}

a Trace $=<0.05 \mu \mathrm{g} \cdot \mathrm{kg}^{-1}$.

Table 4. $\mathrm{N}$-nitrosamine concentrations in the workroom air of the processing shop in the winter. Separate samples taken from the breathing zone in the middle of the morning workshift. (N-DMNA = dimethylnitrosamine, N-DENA = diethylnitrosamine, $\mathrm{SE}=$ standard error)

\begin{tabular}{|c|c|c|c|c|c|}
\hline \multirow{3}{*}{ Type of process } & \multirow{3}{*}{$\underset{(\mathrm{N})}{\text { Samples }}$} & \multicolumn{4}{|c|}{ Concentration $\left(\mu \mathrm{g} \cdot \mathrm{m}^{-3}\right)$} \\
\hline & & \multicolumn{2}{|c|}{ N-DMNA } & \multicolumn{2}{|c|}{ N-DENA } \\
\hline & & Mean & SE & Mean & $\mathrm{SE}$ \\
\hline Weighing, mixing & 4 & 244.0 & 75.5 & 836.6 & 407.8 \\
\hline Milling & 5 & 83.6 & 19.9 & Trace ${ }^{a}$ & \\
\hline $\begin{array}{l}\text { Storage of rubber } \\
\text { plates }\end{array}$ & 5 & 113.8 & 58.5 & 3.6 & 2.1 \\
\hline
\end{tabular}

a Trace $=<0.05 \mu \mathrm{g} \cdot \mathrm{m}^{-3}$.

Table 5. $\mathrm{N}$-dimethylnitrosamine concentrations in the workroom air in the summer. Separate samples taken from the breathing zone in the middle of the morning workshift.

\begin{tabular}{lcc}
\hline Type of prociess & $\begin{array}{c}\text { Samples } \\
(\mathrm{N})\end{array}$ & $\begin{array}{c}\text { Concentration } \\
\left(\mu \mathrm{g} \cdot \mathrm{m}^{-3}\right)\end{array}$ \\
\hline $\begin{array}{l}\text { Raw material handling, } \\
\text { weighing, mixing, milling }\end{array}$ & 4 & $3.9-30.9$ \\
Assembly and building & 1 & 4.5 \\
Curing or vulcanizing & 2 & $2.4 ; 27.0$ \\
Planniug department & 1 & 7.0 \\
\hline
\end{tabular}

ride concentrations ranged from 0.007 to $1.26 \mathrm{mg}$. $\mathrm{m}^{-3}$ with a mean value of 0.25 (SE 0.07$) \mathrm{mg} \cdot \mathrm{m}^{-3}$ (occupational exposure limit $5 \mathrm{mg} \cdot \mathrm{m}^{-3}$ ). At the worksites of the controllers of ready goods $(\mathrm{N}=8)$ the vinyl chloride concentrations were less than the limit of detection $(0.005 \mu \mathrm{g})$.

The content of acrylonitrile varied between nondetectabIe concentrations up to $2.2 \mathrm{mg} \cdot \mathrm{m}^{-3}$. The number of samples was 32 . With the number of samples $(\mathrm{N}=17)$ in which the concentrations were $<0.005 \mu \mathrm{g}$ taken into consideration, the mean value was 0.19 (SE 0.07) $\mathrm{mg} \cdot \mathrm{m}^{-3}$ (occupational exposure limit $0.5 \mathrm{mg} \cdot \mathrm{m}^{-3}$ ).

When eight rubber chemicals were tested for contamination by N-dimethylnitrosamine (N-DMNA) and $\mathrm{N}$-diethylnitrosamine (N-DENA), the highest levels of N-DMNA were found in the widely used thiram $\left(150-22868 \mu \mathrm{g} \cdot \mathrm{kg}^{-1}\right)$ and in diphenylnitrosamine $\left(690 \mu \mathrm{g} \cdot \mathrm{kg}^{-1}\right)$; in other compounds the concentrations were in tens of micrograms per kilogram (table 3 ).

The measured airborne N-DMNA and N-DENA levels ranged from 0.05 up to hundreds of micrograms per cubic meter. In the winter their contents were significantly higher than during the summer (table 4), when the N-DMNA concentrations in the various shops were more or less stable $\left(2.4-30.0 \mu \mathrm{g} \cdot \mathrm{m}^{-3}\right)$ (table 5). Curiously, the N-DMNA content in the office building was close to the level measured in the workshops $\left(7.0 \mu \mathrm{g} \cdot \mathrm{m}^{-3}\right)$, but only one sample was made. The possibility of intraplant migration deserves further study.

\section{Discussion}

Our findings indicate high dust contents bearing both toxic substances (thiram, etc) and carcinogens (BaP, N-NA) in the air of the preparatory shop. Occupational dust exposure is supposedly a risk factor of stomach tumors $(14,15)$. The talc contents were especially high, and this substance, as shown elsewhere, can increase stomach cancer risk (16).

Higher BaP levels in the presser's worksites, especially immediately after the opening of the vulcanization boilers, confirm the possibility of the synthesis or emission of BaP during rubber goods vulcanization. 
Its contents at the studied plant were higher than in comparable sections of tire vulcanization in some British enterprises (17), but, on the whole, the level corresponds with those of other rubber plants $(8,9)$. Within the studied occupational setting and given the average $\mathrm{BaP}$ concentration of $0.12 \mu \mathrm{g} \cdot \mathrm{m}^{-3}$ during an $8-\mathrm{h}$ shift, a worker can inhale about $0.9 \mu \mathrm{g}$ of BaP. This value is 3.5 times the amount reported by Nutt for British tire plants (17).

The extension of this approach to the N-NA concentration shows that during an 8-h shift and given that (i) the volume of inhaled air is $151 \cdot \mathrm{min}^{-1}$ (for average physical labor) and (ii) the mean N-NA concentration in summer is $8.8 \mu \mathrm{g} \cdot \mathrm{m}^{-3}$, the average cumulative intake would be $63.4 \mu \mathrm{g}$. During winter, for workers in the processing section, the daily N-NA intake would be about $1064.0 \mu \mathrm{g}$. The sharp difference in the N-NA levels during the summer and winter may be due to different ventilation rates in the workshop. Therefore, an appropriate technical change can lead to a significant decrease in the N-NA concentrations. An alternative way of diminishing the workers' exposure to these chemicals is to replace currently used and easily nitrosatable rubber compliments by other compounds which are not nitrosatable and can substitute traditional rubber chemicals (10).

The reported data will be used in the interpretation of the results of our epidemiologic study of rubber workers, which is now nearing completion and will be reported later.

\section{References}

1. Case RA, Hosker ME. Tumor of the urinary bladder as an occupational disease in rubber industry in England and Wales. Br J Prev Soc Med 1954;8:39-54.

2. Delzell E, Monson RE. Mortality among rubber workers: III. cause-specific mortality 1930-78. J Occup Med 1981;23:667-84.

3. Andjelkovich D, Taulbee J, Symons M. Mortality experience of a cohort of rubber workers 1964-1973. J Occup Med 1976;18:387-99.

4. Andjelhovich D, Taulbee J, Symons M, Williams T. Mortality of rubber workers with reference to work experience. J Occup Med 1977;19:397-405.
5. Fox AJ, Collier PF. A survey of occupational cancer in rubber and cable making industries: analysis of death occurring in 1972-1974. Br J Ind Med 1976;33:246-64.

6. McMichael A, Spirtas R, Gamble JF, Tousey FM. Mortality among rubber workers: relationship to specific job. J Occup Med 1976;18:178-85.

7. Gustavsson P, Hogstedt C, Holmberg B. Mortality and incidence of cancer among Swedish rubber workers, 1952-1981. Scand J Work Environ Health 1986;12: 538-44.

8. International Agency for Research on Cancer (IARC). Rubber industry. Lyon: IARC, 1982. (IARC monographs on the evaluation of the carcinogenic risk of chemicals to humans; vol 28.)

9. Spiegelhalder B. Carcinogens in the workroom air in the rubber industry. Scand J Work Environ Health 1983;9 (suppl 2):15-25.

10. Wacker CD, Spiegelhalder B, Borzsonyi M, Brune G, Preussmann R. Prevention of exposure to N-nitrosamines in rubber industry: new vulcanization accelerators based on "safe" amines. In: International Agency for Research on Cancer (IARC). The relevance of $\mathrm{N}$-nitroso compounds to human cancer exposures and mechanisms. Lyon: IARC, 1984:372-4. (IARC scientific publication; no 84).

11. Preston-Martin S, Mack W, Henderson BE. Risk factors for gliomas and meningiomas in males in LosAngeles County. Cancer Res 1989;49:6137-43.

12. Symons MJ, Andjelkovich D, Spirtas R, Herman DR. Brain and central nervous system cancer mortality in US rubber workers. Ann NY Acad Sci 1982;381:146-59.

13. Khesina AY. Method 7 - determination of benzo(a)pyrene in extracts by spectroluminescene. In: International Agency for Research on Cancer (IARC). Environmental carcinogens selected methods of analysis; vol 3 (Analysis of polycyclic aromatic hydrocarbons in environmental samples). Lyon: IARC, 1979:215-26. (IARC publication, no 29).

14. Neugut AI, Wylie P. Occupational cancers of the gastrointestinal tract. In: Occupational medicine: state of the art reviews; vol 2. Philadelphia, PA: Hanley \& Belfus Inc, 1987:109-35.

15. Wright WE, Bernstein L, Peters JN, Garanbrandt DH, Mack TM. Adenocarcinoma of the stomach and exposure to occupational dust. Am J Epidemiol 1988; 128:64-73.

16. Katsnelson BA, Mokronosova KA. Non-fibrous mineral dust and malignant tumors: an epidemiological study of mortality. J Occup Med 1979;21:15-20.

17. Nutt A. Rubber work and cancer - past, present and perspectives. Scand J Work Environ Health 1983;9 (suppl 2):49-57.

Received for publication: 7 August 1990 